\title{
Local wisdom-based teaching material for enhancing primary students' scientific literacy skill
}

\author{
Suryanti Suryanti $^{1}$ *, Neni Mariana ${ }^{1}$, Yoyok Yermiandhoko ${ }^{1}$, Wahono Widodo ${ }^{2}$ \\ ${ }^{1}$ Department of Elementary Teacher Education, Universitas Negeri Surabaya. \\ Jalan Kampus Unesa Gedung O2 Lidah Wetan, Lakarsantri, Surabaya 60213, Indonesia \\ ${ }^{2}$ Department of Science Education, Universitas Negeri Surabaya \\ Jalan Kampus Unesa Gedung C12 Ketintang, Gayungan, Surabaya 60231, Indonesia \\ * Corresponding Author. E-mail: suryanti@unesa.ac.id
}

Received: 1 July 2020; Revised: 2 July 2020; Accepted: 7 July 2020

\begin{abstract}
The study aims to develop local wisdom-based teaching materials to improve elementary school students' scientific literacy skills, using a 4-D model: define, design, develop, and disseminate. The subjects of testing included 37 of fourth-grade students at SDN Gading 6 Surabaya. In addition, data were collected through validation sheets, tests of scientific literacy skills, and student questionnaires. The data analysis used descriptive statistics, N-gain, and different tests. The results showed that local wisdom-based teaching materials could be implemented as an alternative source of learning natural science in elementary schools, compliance with the criteria of (a) valid in terms of fulfilling the $98 \%$ validity assessment score with very valid criteria; (b) practical reviewed from the 3.64 scores with very good criteria; (c) effective with a 0.5 average $\mathrm{N}$-gain, there are significant differences between the pretest and posttest scores, and $100 \%$ of positive responses.
\end{abstract}

Keywords: teaching materials, local wisdom, scientific literacy

How to Cite: Suryanti, S., Mariana, N., Yermiandhoko, Y., \& Widodo, W. (2020). Local wisdom-based teaching material for enhancing primary students' scientific literacy skill. Jurnal Prima Edukasia, 8(1), 96-105. doi:https://doi.org/10.21831/jpe.v8i1.32898

\section{Introduction}

Progress and change in all aspects of life change the world quickly. This fact requires students to have a variety of skills that enable them to play an active role and contribute to life now and in the future (Jacobs, 2010; Wilmarth, 2010). The focus of skills needed to be able to survive in the 21st century is the ability to apply their knowledge in various fields of life, thinking skills, and knowledge to meet the future economic era (Windschitl, 2009).

The focus of developing skills for the future of these students is one of the foundations of learning Curriculum 2013 (K13) in Indonesia today. In K13, learning in elementary schools is done thematically and appreciates local wisdom in learning activities (Peraturan Menteri Pendidikan Dan Kebudayaan Republik Indonesia Nomor 81A Tahun 2013 tentang implementasi kurikulum, 2013). One of the methods to implement this mandate is to collaborate with local wisdom (ethnoscience) in learning activities, by utilizing community culture as an alternative source of learning.

In line with this, Sarfiyo and Pannen (Yuliana, 2017), argued that local wisdom is a strategy for creating the environment and planning for learning that integrates culture as part of the learning process of science. In addition, the use of local wisdom is one approach that is suitable for use in education in Indonesia. That is because local wisdom contains knowledge in the form of language, morals, customs, culture, and technology that comes from communities that contain scientific knowledge (Sudarmin et al., 2014).

Empirical evidence that states the importance of integrating local wisdom in learning activities such as research conducted by Okebukola (1986), which shows that students' cultural backgrounds have a greater effect on learning activities than the effects arising from the subject matter itself. Not only increases the results student learning, integration of local wisdom in science learning activities can also 
improve critical thinking skills, the ability to think scientifically in local cultures, and mastery of student concepts (Arfianawati et al., 2016; Damayanti et al., 2017; Wahyuni, 2015; Yuliana et al., 2017).

Unlike previous research, this study emphasizes integrating local wisdom in science learning in elementary schools to enhance their scientific literacy skills. This scientific literacy is necessary for students at elementary level, as it is said that students with high scientific literacy will be able to create and use scientific concepts to analyze, explain, accompanied by relevant evidence, evaluate, and communicate conclusions appropriately (Organization for Economic Co-operation and Development, 2013).

In fact, a new OECD report shows that Indonesia students ranked 73rd in mathematics, 74th in reading, and 71st in science. All scores were also significantly below the OECD average (Schleicher, 2019). Amongst these three competencies, science draws very fluctuating data. It progressed tremendously from 382 in 2012 to 403 in 2015 but decreased slightly to 396 in 2018. These results reflect that the scientific literacy of Indonesian students is still needs improvement.

As Indonesia has abundant natural and cultural resources with various characteristics, East Java is also popular with its wealthy local wisdom. This study, therefore, strives to implement local wisdom into science learning in elementary school. The local wisdom used in this study is from Surabaya, a capital city of East Java, namely clover batik, remo dance, and rujak cingur. Putting local wisdom-based learning into practice requires teaching materials consisting of lesson plans, students' activity sheets, and scientific literacy tests. Hence, this study aims to develop teaching materials based on local wisdom as sources of natural science learning.

\section{Method}

This research aims to develop teaching materials based on local wisdom as one of the sources of natural science learning. It is a developmental study using four-D models: define, design, develop, and disseminate. The products produced are in the form of learning tools based on local wisdom in elementary schools consisting of teaching materials, lesson plans, student's activity sheet, and science literacy tests. The selected local wisdoms are clover batik, remodance, and rujak cingur.

Participants

The population of the study included 115 fifth grade students of SD Gading 6 Surabaya. By using cluster random sampling technique, A class-consisting of 37 students-was selected as the research sample.

Instrument

The instruments used in this study include validation sheets, observation sheets, science literacy tests, and student questionnaires.

\section{Validation Sheet}

The validation sheet was developed as a validity's guideline in assessing the quality of learning tools comprising teaching materials, lesson plans, student activity sheets, and scientific literacy tests.

\section{Observation Sheet}

The observation sheet was elaborated as an observer's guide in assessing the implementation of learning by using local wisdom-based learning tools. It comprised the learning activities: opening lessons, motivating, delivering goals, asking questions, discussing important concepts, guiding investigation activities, presenting work, guiding discussions, guiding conclusions making, giving follow-up tasks, and closing greetings/prayers.

\section{Sciences Literacy Test}

The scientific literacy test referred to the achievement indicators develop from learning indicators. It was adjusted to the PISA-OECD indicator containing problem solving questions. 20 multiple-choice questions were comprised to fulfil the requirements.

\section{Student's Questionnaire}

After the learning process was completed, the student's questionnaires were distributed to the students. It was in the form of open questions and evolved to find out the students' responses after following the local wisdom-based learning process. 
Jurnal Prima Edukasia, 8 (1), 2020 - 98

Suryanti Suryanti, Neni Mariana, Yoyok Yermiandhoko, Wahono Widodo

Data Analysis

Analysis of the data in this study included the validity, practicality, and effectiveness of local wisdom-based learning tools.

\section{Data Validity}

The validity of the learning tools was the results of the assessment of 2 validatories using validity assessment instruments.

Table 1. Data Validity Criteria

\begin{tabular}{cc}
\hline Cr & Category \\
\hline $0-20$ & invalid \\
$21-40$ & less valid \\
$41-60$ & quite valid \\
$61-80$ & Valid \\
$81-100$ & very valid \\
\hline
\end{tabular}

(Adapted from Skala Likert in Riduwan and Sunarto (2011)

The reliability of the assessment results of the validity of the teaching materials based on local wisdom is calculated based on the percentage of agreement Formula 1:

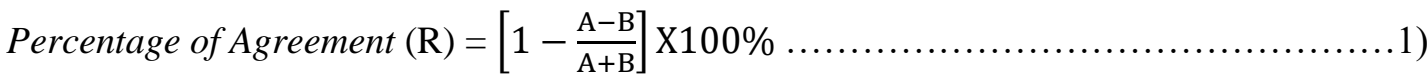

Information:

$\mathrm{R} \quad$ : Coefficient inter-observer agreement.

A-B : High-value validator evaluations.

$\mathrm{A}+\mathrm{B} \quad$ : Low-value validator evaluations.

(Borich, 2016)

The results of the assessment of learning tools validity based on local wisdom are reliable if a percentage of agreement is $\geq 75 \%$.

\section{Data Practicality}

The practicality of local wisdom-based learning tool is obtained through a score given by the compile observer to assess in a class by providing an interval score of 1-4. The criteria for learning delays are the average score and the number of learning delays in Table 2.

Table 2. Criteria for Lessons Plan

\begin{tabular}{cc}
\hline Score & Criteria \\
\hline 4 & Very good \\
3 & Good \\
2 & Enough \\
1 & Less \\
\hline
\end{tabular}

(Sugiyono, 2015)

\section{Data effectiveness}

The scientific literacy scores and the students' questionnaires as a source of data for studying effectiveness of local wisdom-based learning tools. Scientific literacy from students will be analyzed descriptively by $\mathrm{N}$-Gain $(\langle\mathrm{g}\rangle)$ analysis. The score is obtained from a comparison between actual gain score with the maximum gain score (Hake, 1999).

$$
<g>=\frac{\%<G>}{\%<G>\max }=\frac{\left(\%<\mathrm{S}_{\mathrm{f}}>-\%<\mathrm{S}_{\mathrm{i}}>\right)}{\left(100-\%<\mathrm{S}_{\mathrm{i}}>\right)}
$$

Note:

$\langle\mathrm{g}\rangle \quad=$ normalized gain score;

$\mathrm{Sf} \quad=$ average posttest score;

$\mathrm{Si} \quad=$ average pretest score

The levels of the normalized gain score are categorized in three categories, as seen in Table 3. 
Jurnal Prima Edukasia, 8 (1), 2020 - 99

Suryanti Suryanti, Neni Mariana, Yoyok Yermiandhoko, Wahono Widodo

Table 3. Normalized gain score criteria

\begin{tabular}{cc}
\hline Score & Criteria \\
\hline$(<\mathrm{g}>) \geq 0.7$ & High Gain \\
$0.7>(<\mathrm{g}>) \geq 0.3$ & Medium Gain \\
$(<\mathrm{g}>)<0.3$ & Low Gain \\
\hline
\end{tabular}

(Meltzer, 2002)

A paired sample t-test was performed using SPSS version 20 statistical tools to find out the mean differences between the pre-test and post-test scores. To overview the students' responses about implementation of learning, researchers spread open questionnaires, and each student can write their own learning experiences. The results of the student response questionnaire will then analyzed descriptively by percentage and then described.

\section{Results and Discussions}

Local Wisdom-Based Teaching Materials

The teaching materials developed in this study are local wisdom-based teaching materials, namely clover batik, remodance, and rujak cingur, using four-D models (define, design, develop, and disseminate) with the following details.

\section{Define}

The activities carried out at this stage were interviewing and observing with local wisdom activists in Surabaya, namely clover batik craftsmen, Remo dance activists, and rujak cingur sellers. The results of the interviews were then carried out an analysis of the context of local wisdom through a transformation from everyday society term to scientific term, such as the following example.

Table 4. Analysis of local wisdom context

\begin{tabular}{ll}
\hline \multicolumn{1}{c}{ Society Term } & \multicolumn{1}{c}{ Scientific Term } \\
\hline $\begin{array}{l}\text { When dyeing cloth, a salt solution used to } \\
\text { strengthen the color. }\end{array}$ & $\begin{array}{l}\text { Mordant is a metal salt that is added to a dip solution to } \\
\text { increase color intensity. }\end{array}$ \\
$\begin{array}{l}\text { The use of stone mortar to make spices quickly } \\
\text { fine. }\end{array}$ & $\begin{array}{l}\text { The frictional force is affected by the rough surfaces that } \\
\text { touch each other. }\end{array}$ \\
\hline
\end{tabular}

After discovering the context of scientific term derived from the science of society, then analyzing the elementary school curriculum to look for the relationship of the context of scientific term with curriculum.

Design

Activities at the design stage are designing prototypes of teaching materials comprising student book, lesson plans, student worksheets, and scientific literacy tests that integrate local wisdom. The teaching material developed has criteria of (a) based on local wisdom; (b) according to the characteristics and intellectual and social development of elementary students; (c) according to learning materials in elementary school; and (d) able to practice daily problem-based scientific literacy. Systematic of each chapter in the teaching material includes: objectives, introductions, learning materials, activities, exercises, and bibliography.

\section{Develop}

The development phase activity is to develop teaching materials following the design stage. Teaching materials that were successfully developed were then subjected to expert validation and limited trials. In the research development that has been done before, teaching materials have been produced. The teaching material contains and combines the local wisdom of the city of Surabaya with the concepts of elementary school science which are in Grade 4 and part of the Grade 5.

The characteristics of the teaching material are as follows: (1) contains and integrates the local wisdom of the city of Surabaya with elementary science concepts; (2) For Grade 4 students, teaching materials cover concepts: the shape and function of plant and animal body parts, force and motion, sound and its relation to the sense of hearing, and light and its relation to the sense of sight. Whereas teaching 
Jurnal Prima Edukasia, 8 (1), 2020 - 100

Suryanti Suryanti, Neni Mariana, Yoyok Yermiandhoko, Wahono Widodo

materials for Grade5 includes: heat and propagation, as well as changes in temperature and shape of objects. Here are some descriptions of these teaching materials.

\section{Gaya pada Tari Remo}

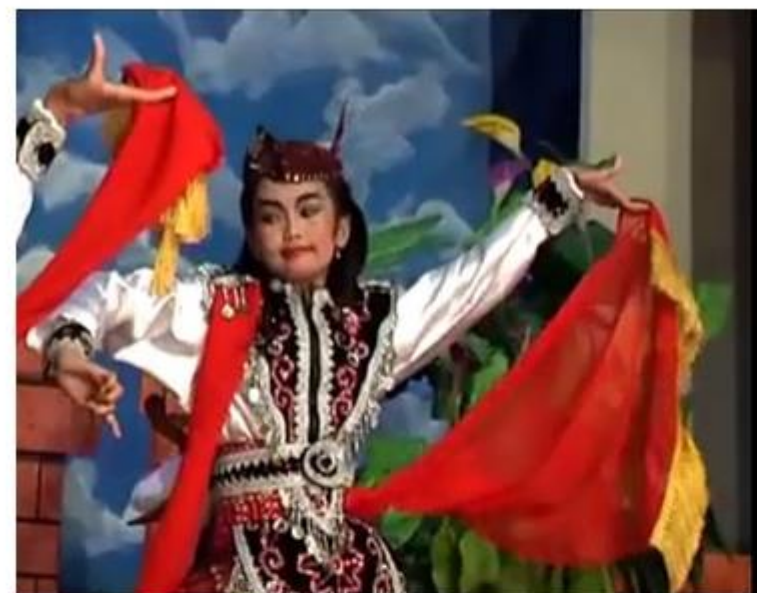

Pada Tari Remo, penari melakukan berbagai gerak tarian. Perhatikan gerakan gedruk lombo pada Gambar 3. Penari menggunakan gaya otot untuk mengatur gerak tangan dan kaki secara dinamis. Gaya otot juga diperlukan untuk mengibaskan sampur atau selendang penari.

Apakah ada gaya lain yang terlibat? perhatikan, ujung sampur setelah dikibaskan akan menjuntai ke bawah. Hal ini dapat terjadi, karena sampur yang ditahan dengan gaya otot tangan tadi mendapatkan gaya gravitasi. Akibatnya, ujung sampur berkibar ke bawah dengan indah.

Lebih jelas lagi, dapat kam perhatikan Gambar 4. Pada gerakan nebak bumi, sampur yang dilempar ke samping atas dengan gaya otot, selanjutnya akan meluncur jatuh ke bawah oleh gaya gravitasi, lalu ditarik menuju ke penari dengan gaya otot. Dengan pengaturan gaya ini, maka akan didapat gerak tubuh dan sampur yang indah.
Gambar 3. Gaya otot dan gravitasi pada Gerak GedrukLombo

Sumber: Dokumentasi penulis

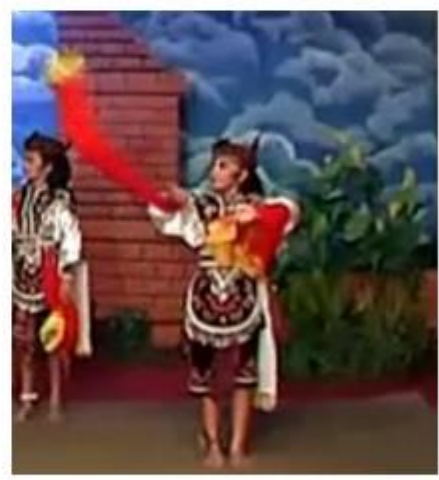

Gambar 4. Perpaduan gaya otot dan gaya gravitasi padagerak Nebak Bumi menjadikan sampur berkelebatdengan indah

Sumber:Dokumentasi penulis

Figure 1. An Illustration of the Developed Teaching Materials

Teaching MaterialsValidity

Teaching materials validation is used to determine the validity of the learning materials developed. The results of the learning materials validation are summarized in Table 5.

Table 5. Percentages of the Teaching Materials Validity

\begin{tabular}{lllll}
\hline Learning Tools & Average Score & Note & Reliability & Note \\
\hline Student Book & 100 & Very Valid & 1.00 & Reliable \\
Lesson plan & 96 & Very valid & 0.99 & Reliable \\
Worksheet & 100 & Very Valid & 1.00 & Reliable \\
Scientific Literacy Tests & 96 & Very valid & 0.99 & Reliable \\
Average & 98 & Very valid & 99.5 & Reliable \\
\hline
\end{tabular}


Based on Table 5 means that Student Book and Worksheet developed are very valid with a average score 100. Likewise, the lesson plans and scientific literacy tests developed are also very valid with average score 96 . On average, the learning tools developed in the category are very good with a percentage of 98 and the experts judgmentswere consistent, with average reliability of 99.5.

Practicality

The practicality of local wisdom-based teaching materials was from the assessment conducted by the observer by observing the activities of the teacher in implementing the materials in the classroom. Data on observations of teacher activities are presented below.

Based on the Table 6, implementing local wisdom-based teaching materials got 3.64 score with a very good category. This shows that the mentioned learning could be administered to enhance the students' scientific literacy.

Table 6. Data Observation of Teacher Activity

\begin{tabular}{clcc}
\hline No. & \multicolumn{1}{c}{ Learning Activities } & Score & Information \\
\hline 1. & Preliminary & & \\
& Open learning activities (greetings, presence, and prayers) & 4 & Very Good \\
& Motivating & 3 & Good \\
Delivery of learning objectives & 4 & Very Good \\
The questions students want to ask & 3 & Good \\
2. & & \\
Core & 4 & Very Good \\
Discuss the concepts of learning material by teachers and students & 4 & Very Good \\
Guide the investigation or discovery activities individually or in groups. & Very Good \\
activities. & 4 & \\
Closing & & Good \\
Provide opportunities to talk/ask questions and add information. & 3 & Baik \\
Provide reinforcement and conclusions. & 3 \\
Assign students to learn further learning. & 4 & Very Good \\
Greetings and closing prayers & 4 & Very Good \\
Average Score & $\mathbf{3 . 6 4}$ & Very Good \\
\hline
\end{tabular}

\section{Effectiveness}

The effectiveness of the teaching materials in improving scientific literacy is seen from the scores of students' scientific literacy tests and the results of the student questionnaire. Scientific literacy was measured by involving knowledge domain mastery, context, and scientific competencies the students had. The data can be seen in Table 7.

Based on Table 7, it is known that the local wisdom-based teaching materials are effective for students training scientific literacy skills. This fact appears from the increase in scientific literacy scores between before and after learning activities using learning tools, which is as much as 25 scores from the pre-test score. The $\mathrm{N}$-Gain is 0.5 in the medium category. Then, a paired sample t-test was conducted to find out the impact of the implementation of the pretest and posttest values. Requirements to do the t-test and the assumption test are needed to fulfill the normality and homogeneity categories. The results of the normality, homogeneity, and paired sample tests are presented in Table 8.

Table 8 shows that local wisdom-based teaching materials increased the students' scientific literacy with a 0.05 significance level. At the end of the learning process, students are asked to fill in questionnaires to find out how they respond to local wisdom - based teaching material. There are 10 question items in the student response questionnaire. Based on the results of the questionnaire, it knows that students give a positive impression of teaching materials and learning activities using learning materials based on local wisdom. The results are 100\% students feel happy (fun: $81 \%$ andexciting: $19 \%$ )with the learning activities. The students felt very clear $46 \%$, and $54 \%$ felt clear about how the teacher's explanation because the teacher was able to guide well (40\%) and quite well (60\%).In addition, $78 \%$ of students also find it easy to understand and $22 \%$ quite easily understand the concepts of science taught by using teaching materials that are developed. By using these teaching materials, students find it easy and helpful to apply concepts that are understood to solve scientific literacy problems, practice investigating or solving problems. 
Jurnal Prima Edukasia, 8 (1), 2020 - 102

Suryanti Suryanti, Neni Mariana, Yoyok Yermiandhoko, Wahono Widodo

Table 7. Students Scientific Literacy Test Result

\begin{tabular}{|c|c|c|c|c|}
\hline \multirow{2}{*}{ No. Subject } & \multicolumn{2}{|c|}{ Score } & \multirow{2}{*}{ N Gain } & \multirow{2}{*}{ Note } \\
\hline & Pre-test & Post-test & & \\
\hline 1. & 47 & 68 & 0.4 & Medium \\
\hline 2. & 46 & 83 & 0.7 & Medium \\
\hline 3. & 46 & 72 & 0.5 & Medium \\
\hline 4. & 47 & 72 & 0.5 & Medium \\
\hline 5. & 34 & 81 & 0.7 & Medium \\
\hline 6. & 76 & 83 & 0.3 & Medium \\
\hline 7. & 48 & 84 & 0.7 & Medium \\
\hline 8. & 71 & 76 & 0.2 & Low \\
\hline 9. & 46 & 83 & 0.7 & Medium \\
\hline 10. & 35 & 44 & 0.1 & Low \\
\hline 11. & 34 & 100 & 1.0 & High \\
\hline 12. & 53 & 93 & 0.9 & High \\
\hline 13. & 54 & 70 & 0.3 & Medium \\
\hline 14. & 46 & 76 & 0.6 & Medium \\
\hline 15. & 67 & 100 & 1.0 & High \\
\hline 16. & 46 & 53 & 0.1 & Low \\
\hline 17. & 41 & 87 & 0.8 & High \\
\hline 18. & 48 & 72 & 0.5 & Medium \\
\hline 19. & 47 & 55 & 0.2 & Low \\
\hline 20. & 71 & 74 & 0.1 & Low \\
\hline 21. & 38 & 49 & 0.2 & Low \\
\hline 22. & 68 & 73 & 0.2 & Low \\
\hline 23. & 49 & 50 & 0.0 & Low \\
\hline 24. & 29 & 57 & 0.4 & Medium \\
\hline 25. & 64 & 100 & 1.0 & High \\
\hline 26. & 34 & 82 & 0.7 & Medium \\
\hline 27. & 54 & 61 & 0.2 & Low \\
\hline 28. & 40 & 65 & 0.4 & Medium \\
\hline 29. & 41 & 94 & 0.9 & High \\
\hline 30. & 43 & 76 & 0.6 & Medium \\
\hline 31. & 61 & 64 & 0.1 & Low \\
\hline 32. & 50 & 90 & 0.8 & High \\
\hline 33. & 59 & 96 & 0.9 & High \\
\hline 34. & 44 & 60 & 0.3 & Medium \\
\hline 35. & 72 & 83 & 0.4 & Medium \\
\hline 36. & 56 & 82 & 0.6 & Medium \\
\hline 37. & 44 & 81 & 0.7 & Medium \\
\hline Average & 50 & 75 & 0.5 & Medium \\
\hline
\end{tabular}

Table 8. Result of Scientific Literacy Test Statistics

\begin{tabular}{lccccc}
\hline \multicolumn{1}{c}{ Statistics test } & & Score & $\mathrm{P}$ & Result & Information \\
\hline Normality & Pretes & 0.058 & 0.05 & $0.058>0.05$ & Normal \\
& Postes & 0.396 & 0.05 & $0.396>0.05$ & Normal \\
Homogeneity & Pretes \& postes & 0.184 & 0.05 & $0.184>0.05$ & Homogeneous \\
Paired Sampel t-test & & 0.000 & 0.05 & $0.000<0.05$ & H$_{0}$ rejected \\
Paired Differences & & Lower & & -30.900 & (There is a difference) \\
& & Upper & & -19.911 & \\
& $\mathrm{t}$ & & & -9.377 & \\
& $\mathrm{df}$ & & & 36 & \\
\hline
\end{tabular}

Discussion

The results of the study revealed that the scientific literacy skills at the post-test stage increased compared to the pre-test stage. The improvement of students' scientific literacy skills was influenced by several factors. First, teaching materials developed by integrating the local wisdom of Surabaya were entities closed to students' daily lives. Learning becomes more contextual as they learn about science concepts through things in their surrounding area. They could easily understand that the real concepts 
of science are not only theories but also facts and reality. Next, the learning tools evolved to facilitate the practice of scientific literacy guided them to solve questions and problems. Last, students are enthusiastic about participating in learning activities indicated by their positive responses during the learning process.

Besides, the findings also reflected that the scientific literacy of Indonesian students could be trained and improved by using meaningful activities using local wisdom materials. This is also in line with Inzanah et al. (2017) and Pravitasari (2015) research. The results showed that the students were interested in reading, thinking, conducting investigations, and decisions related to the socio-scientific issues when they were involved in creative activities. The creative ways were using flip-books (Maghfirothi, 2013) and blogs (Pravitasari, 2015).

The results of this study also enriched learning/teaching material based on various local Indonesian wisdom, for example the research of Laksono and Wahyuni (2018) which uses 7 local wisdom areas of Jember Indonesia for learning materials that improve functional literacy skills. In addition, local wisdom of Bugis Indonesia (Ardi et al., 2019) has also been revealed, as well philosophy of sufficiency economy, moral infusion, and the Buddhism way of life in Thailand to organize science learning emphasizing the relationship between science, technology and society based on the Thai context (Yuenyong \& Narjaikaew, 2009) which also has the potential for learning material. The results of this study also broaden the scope of research into the use of local wisdom to increase scientific literacy in Setiawan et al. (2017) who package it into a science learning module, and integrating local wisdom in the ELSII learning model to improve problem solving skills and scientific communication (Dewi et al., 2017).

Moreover, using the environment as a source of learning has many positive impacts on students. It makes them easier to understand the subject, get in touch with actual environmental conditions, and inspire them to apply knowledge and skills in daily life, and encourage them to take part in maintaining and protecting the environment. As Rouseau (Barlia, 2009) said that children should learn directly from their own experience, rather than just rely on information from books. The students' first teacher was their parts of bodies and senses that guide them to think.

In addition, Liliasari (2015) was also in line with the findings of the study by explaining that students who master scientific literacy can use their knowledge of science concepts and processes to evaluate issues and problems and determine the decisions they make in their daily lives (Aryani et al., 2016; Khoiriah \& Kholiq, 2019). This indicates that students with scientific literacy skills can use science concepts to explain phenomena and solve problems in their lives. Hence, using local wisdom integrated with learning activities is one of the alternative ways to improve students' scientific literacy skills.

\section{Conclusion}

Based on the research result, it can be concluded that local wisdom-based learning using learning materials which integrate local wisdom is valid and effective to train elementary students' scientific literacy up to level 5. Teaching materials based on local wisdom were valid, practical, and effective to implement. The validity was proved by obtaining $98 \%$ validity value with a very valid category. Then, the practicality was supported by 3.64 scores with very good categories. Meanwhile, the effectiveness was established by the $\mathrm{N}$-gain of 0.5 in the medium category. Moreover, this implementation gets a positive response from students indicated by the increasing mastery of scientific literacy with a 0.05 significance level. This shows that local wisdom - based teaching material is a veryentrusted alternative learning resource in enhancing students' scientific literacy skills.

\section{References}

Ardi, M., Lullulangi, M., \& Amir, F. (2019). Design of local wisdom based resident of bugis tribe with environmental insights (Study on supporting facilities aspects). International Journal of Architecture, Arts and Applications, 5(4), 82-88. https://doi.org/10.11648/j.ijaaa.20190504.11

Arfianawati, S., Sudarmin, M., \& Sumarni, W. (2016). Model pembelajaran kimia berbasis etnosains untuk meningkatkan kemampuan berpikir kritis siswa. Jurnal Pengajaran MIPA, 21(1), 46-51. https://doi.org/10.18269/jpmipa.v21i1.669

Aryani, K., Suwono, A., \& Parno, H. (2016). Profil kemampuan literasi sains siswa SMPN 3 Batu. Prosiding Seminar Nasional Pendidikan IPA, 847-855. 
Barlia, L. (2009). Teori pembelajaran sains di sekolah dasar. Royyan Press.

Borich, G. D. (2016). Observation skills for effective teaching: Research-based practice. Routledge.

Damayanti, C., Rusilowati, A., \& Linuwih, S. (2017). Pengembangan model pembelajaran IPA terintegrasi etnosains untuk meningkatkan hasil belajar dan kemampuan berpikir kreatif. Journal of Innovative Science Education, 6(1), 116-128. https://doi.org/10.15294/JISE.V6I1.17071

Dewi, I. N., Poedjiastoeti, S., \& Prahani, B. K. (2017). ELSII learning model based local wisdom to improve students' problem solving skills and scientific communication. International Journal of Education and Research, 5(1), 107-118.

Hake, R. R. (1999). Analyzing change/Gain scores. http://www.physics.indiana.edu/ sdi/AnalyzingChange-Gain.pdf

Inzanah, I., Ibrahim, M., \& Widodo, W. (2017). Pengembangan perangkat pembelajaran IPA berbasis Kurikulum 2013 untuk melatih literasi sains siswa SMP. JPPS (Jurnal Penelitian Pendidikan Sains), 4(1), 459. https://doi.org/10.26740/jpps.v4n1.p459-467

Jacobs, H. H. (2010). Curriculum 21: Essential education for a changing world. Association for Supervision and Curriculum Development.

Khoiriah, M., \& Kholiq, A. (2019). Validitas perangkat pembelajaran fisika berbantuan e-book literasi sains pada materi fluida dinamis. Inovasi Pendidikan Fisika, 9(1). https://jurnalmahasiswa.unesa.ac.id/index.php/inovasi-pendidikan-fisika/article/view/30739

Laksono, B. A., \& Wahyuni, S. (2018). An investigation of local wisdom to support adult literacy program. PEOPLE: International Journal of Social Sciences, 4(2). https://grdspublishing.org/index.php/people/article/view/1559

Liliasari, L. (2015). Persiapan literasi sains generasi muda menjelang ASEAN Community. Prosiding Seminar Nasional IV Pendidikan Sains.

Maghfirothi, N. L. (2013). Pengembangan flip book IPA terpadu bilingual dengan tema minuman berkarbonasi untuk kelas VIII SMP. Pensa: Jurnal Pendidikan Sains, 1(3). https://jurnalmahasiswa.unesa.ac.id/index.php/pensa/article/view/3606

Meltzer, D. E. (2002). The relationship between mathematics preparation and conceptual learning gains in physics: A possible "'hidden variable" in diagnostic pretest scores. American Journal of Physics, 70(12), 1259-1268. https://doi.org/10.1119/1.1514215,

Peraturan Menteri Pendidikan dan Kebudayaan Republik Indonesia Nomor 81A tahun 2013 tentang implementasi kurikulum, Pub. L. No. 81A (2013).

Okebukola, P. A. (1986). The influence of preferred learning styles on cooperative learning in science. Science Education, 70(5), 509-517. https://doi.org/10.1002/sce.3730700505

Organization for Economic Co-operation and Development. (2013). PISA 2015: Draft science framework. OECD Publishing. https://www.oecd.org/pisa/pisaproducts/Draft PISA 2015 Science Framework .pdf

Pravitasari, O. T. (2015). Pengembangan media pembelajaran blog berorientasi literasi sains pada sub materi perpindahan kalor. Pensa E-Jurnal: Pendidikan Sains, 3(3). https://jurnalmahasiswa.unesa.ac.id/index.php/pensa/article/view/12427

Riduwan, R., \& Sunarto, S. (2011). Pengantar statistika untuk penelitian pendidikan, sosial, ekonomi, komunikasi dan bisnis. Alfabeta.

Schleicher, A. (2019). PISA 2018: Insights and interpretations. OECD Publishing. https://www.oecd.org/pisa/PISA 2018 Insights and Interpretations FINAL PDF.pdf

Setiawan, B., Innatesari, D. K., Sabtiawan, W. B., \& Sudarmin, S. (2017). The development of local wisdom-based natural science module to improve science literation of students. Jurnal Pendidikan IPA Indonesia, 6(1). https://doi.org/10.15294/jpii.v6i1.9595

Sudarmin, S., Subekti, N., \& Fibonacci, A. (2014). Model pembelajaran kimia berbasis etnosains (MPKBE) untuk mengembangkan literasi sains siswa. Prosiding Seminar Nasional IV Pendidikan Sains, 83-90.

Sugiyono. (2015). Metode penelitian pendidikan: Pendekatan kuantitatif, kualitatif, dan $R \& D$. 


\section{Jurnal Prima Edukasia, 8 (1), 2020 - 105}

Suryanti Suryanti, Neni Mariana, Yoyok Yermiandhoko, Wahono Widodo

Alfabeta.

Wahyuni, S. (2015). Developing science learning instruments based on local wisdom to improve students'critical thinking skills. Jurnal Pendidikan Fisika Indonesia, 11(2), 156-161. https://repository.unej.ac.id/handle/123456789/73670

Wilmarth, S. (2010). Five socio-technology trends that change everything in learning and teaching. In H. H. Jacobs (Ed.), Curriculum 21 (pp. 80-96).

Windschitl, M. (2009). Cultivating 21st century skills in science learners: How systems of teacher preparation and professional development will have to evolve. In National academies of science workshop on 21 st century skills. University of Washington.

Yuenyong, C., \& Narjaikaew, P. (2009). Scientific literacy and Thailand science education. International Journal of Environmental and Science Education, 4(3), 335-349. http://www.ijese.net/makale/1399

Yuliana, I. (2017). Pembelajaran berbasis etnosains dalam mewujudkan pendidikan karakter siswa sekolah dasar. Jurnal Pendidikan Dan Pembelajaran Sekolah Dasar, 1(2a), 98-106. https://doi.org/10.30651/else.v1i2a.1051

Yuliana, Sriyati, S., \& Sanjaya, Y. (2017). Local wisdom of Ngata Toro community in utilizing forest resources as a learning source of biology. AIP Conference Proceedings, 100007. https://doi.org/10.1063/1.4995217 